\title{
Investigation of PRL-Rsal and Haelll gene polymorphisms in Anatolian water buffaloes bred by using PCR-RFLP method
}

\author{
Yusuf Özşensoy ${ }^{1 *}$ \\ ${ }^{1}$ Cumhuriyet University, Faculty of Veterinary Medicine, Department of Veterinary Biometrics and Genetics, Sivas, Turkey.
}

\begin{abstract}
The objective of this study was to investigate polymorphisms both in exons 1 and 3 of prolactin (PRL) gene for milk productivity of Anatolian water buffalo breed in Sivas province in Turkey. Blood samples were collected from 129 male and female water buffaloes and DNA was isolated by using phenol/chloroform method. Samples of DNA were amplified and resulting PCR products were digested with RsaI (for exons 1 and 3) and HaeIII (for exon 1). Allelic polymorphisms were determined by separation of fragments obtained from digested PCR products in 3\% agarose gel electrophoresis. AA genotype (HaeIII) and BB genotype (RsaI) of exon 1 and only AA genotype (RsaI) of exon 3 were obtained. No polymorphisms were determined in Anatolian water buffalo breed and all loci were found as monomorphic. It can be stated that Anatolian water buffalo has a higher milk and milk fat yields since BB genotype was obtained.
\end{abstract}

Key Words: HaeIII, PCR-RFLP, prolactin, RsaI, Sivas

\section{Introduction}

Water buffaloes are raised in various countries for their economic value and as sources of workforce, meat, milk, leather, and horn (Michelizzi et al., 2010). It has been reported that all water buffalo breeds in Europe, including Anatolian water buffalo, belong to river water buffalo subspecies. However, it has been stated that Anatolian water buffalo breed is more similar to water buffaloes raised in the Mesopotamia region (FAO, 2005; Michelizzi et al., 2010).

Water buffaloes have many drawbacks in breeding, such as lower reproductive performance and higher infertility rates compared with cattle breeds, limited productivity rates, and lower survivability of their calves (Michelizzi et al., 2010). Therefore, molecular studies for determining their productivity traits are needed.

For selection of farm animals, choosing polymorphic genes as molecular markers is a useful approach. Milk fat and milk composition are important genetic selection traits for dairy animals. One of the most important hormones for prediction of milk yield and quality is prolactin (PRL), which has direct effects on milk yield. Therefore, PRL

Received: July 5, 2017

Accepted: October 27, 2017

*Corresponding author: yusufozsensoy@yahoo.com

Copyright (C) 2018 Sociedade Brasileira de Zootecnia. This is an Open Access article distributed under the terms of the Creative Commons Attribution License (http://creativecommons.org/licenses/by/4.0/), which permits unrestricted use, distribution, and reproduction in any medium, provided the original work is properly cited. gene is a significant genetic marker. Studies regarding the polymorphisms in PRL gene have been conducted either in PRL exon 1 or exon 3; however, most of the studies were directed towards PRL exon 3. RsaI restriction enzyme (RE) digestion in exon 3 of PRL resulted in two allelic polymorphisms (B and $\mathrm{b}$ ) associated with milk productivity (Freeman et al., 2000; Alipanah et al., 2007). According to a study carried out with water buffaloes of both Murrah and Nili-Ravi breeds, results showed that $\mathrm{A}_{-}$allele has the highest frequency ( 0.93 and 0.84 , respectively) and no BB genotype was obtained (Mitra et al., 1995). In another study conducted with Murrah water buffalo breed, RsaI RE digestion of PRL exon 3 resulted in no fragments and only monomorphic AA genotype was obtained, which was considered as breed characteristic (Biradar et al., 2014). When different RE were used to digest PRL exon 3 from different dairy breeds in India, the highest genotype frequency was found in $\mathrm{AA}(0.55)$ and the lowest was in $\mathrm{BB}$ (0.06) (Kumari et al., 2008). In another study, even though both $\mathrm{AB}$ and $\mathrm{BB}$ genotypes of PRL exon 3 were obtained from four different Indian breeds, no AA genotype was observed. The highest frequency of genotypes and alleles was found as $\mathrm{AB}(0.87-0.97)$ and $\mathrm{B}$ allele (0.50-0.57), respectively (Ladani et al., 2003a). According to a study conducted with Pandharpuri water buffalo breed, PRL exon 1 was digested by HaeIII RE and no polymorphism was found. Therefore, it was determined that Pandharpuri water buffalo breed was monomorphic for AA genotype (Madnalwar et al., 2010). 
Traditionally, Anatolian water buffalo is raised in various provinces of Turkey (Governmental Newspaper, 2012). However, with the grants from national domestication campaign of "National Domestication by Breeders", water buffalo breeding has increased throughout Turkey. It is known that Anatolian water buffalo breed is raised for both their meat and milk. The Anatolian water buffalo was declared as one of the national genetic resource in 2004 (Governmental Newspaper, 2004). There have been very sparse studies regarding molecular characterization of Anatolian water buffalo breed (Kaplan and Boztepe, 2000; Konca and Akyüz, 2017). Therefore, there is a need for the molecular characterization of Anatolian water buffalo breed. Since Anatolian water buffalo breed is mainly raised for its milk, this study focused upon PRL gene and both exons 1 and 3 were investigated by using high amounts of samples. The present study is among the first in literature in which both PRL exons were investigated at the same time.

The objective of this study was to investigate polymorphisms in both PRL exons 1 and 3 related to milk productivity by using polymerase chain reaction-restriction fragment length polymorphism (PCR-RFLP) method in Anatolian water buffalo breed in Sivas province in Turkey.

\section{Material and Methods}

Blood sampling was carried out from Anatolian water buffalo breed raised by various breeders throughout Sivas province and care was taken not to choose closely related animals. A total of 129 animals, of which 89 were females and 40 were males, were used. Blood samples were collected into $\mathrm{K}_{3}$-EDTA tubes and then kept in $-20{ }^{\circ} \mathrm{C}$ until analyses. Extraction of DNA from blood samples was done by using standard phenol/chloroform method (Sambrook et al., 1989).
Samples of DNA were amplified by using gene specific primers (Table 1). Polymerase chain reaction was performed in $15 \mu \mathrm{L}$ volume containing $1 \times \mathrm{Mg}^{++}$free PCR buffer (Thermo Scientific, USA), 200 mM dNTPs (Thermo Scientific, USA), $1.5 \mathrm{mM} \mathrm{MgCl}{ }^{++}$(Thermo Scientific, USA), 0.375 U Taq polymerase (Thermo Scientific, USA), $5 \mathrm{pM}$ of each primer, and 50-100 ng DNA.

Polymerase chain reactions were amplified by using touchdown PCR profile (Don et al., 1991). In this profile, denaturation was achieved at $95{ }^{\circ} \mathrm{C}$ for $4 \mathrm{~min}$. In the first phase, steps included $30 \mathrm{sec}$ denaturation at $94{ }^{\circ} \mathrm{C}, 30 \mathrm{sec}$ annealing which started at $60{ }^{\circ} \mathrm{C}$ and lowered by $0.5{ }^{\circ} \mathrm{C}$ in each cycle for ideal primer hybridization, and $30 \mathrm{sec}$ elongation at $72{ }^{\circ} \mathrm{C}$. Steps cycled 16 times. In the second phase, steps included $30 \mathrm{sec}$ at $94{ }^{\circ} \mathrm{C}, 30 \mathrm{sec}$ at $52{ }^{\circ} \mathrm{C}$, and $30 \mathrm{sec}$ at $72{ }^{\circ} \mathrm{C}$. Steps cycled 25 times. The final extension of $72{ }^{\circ} \mathrm{C}$ for $10 \mathrm{~min}$ was applied in all reactions. For the amplification of 857 base pairs (bp) long region of PRL gene, durations of annealing and elongation increased by $1 \mathrm{~min}$. Amplified PCR products were then separated in $2 \%$ agarose gel electrophoresis.

Digestions of RE (Table 1) were carried out in $31 \mu \mathrm{L}$ reaction volumes. Reaction volumes contained $10 \mu \mathrm{L}$ PCR product, $1 \mu \mathrm{L}$ RE (10 $\mathrm{U}_{\mu \mathrm{L}^{-1}}$ ) (Thermo Scientific, USA), $2 \mu \mathrm{L}$ enzyme buffer, and $18 \mu \mathrm{L} \mathrm{ddH}_{2} \mathrm{O}$ and reactions were incubated overnight at $37{ }^{\circ} \mathrm{C}$. Fragments obtained from digestions were run in 3\% agarose gel electrophoresis at $100 \mathrm{~V}$ for $1 \mathrm{~h}$. Fragment localizations were then visualized under 365 nm UV.

Genotypic and allelic frequencies were determined by gene counting (Table 2). Differences in polymorphisms were then determined by chi-square analysis.

Research on animals was carried out with the permission granted by the local Ethics Commission for Animal Experimentations (case no. 65202830-122).

Table 1 - Primers and restriction enzymes used in the study

\begin{tabular}{|c|c|c|c|c|}
\hline Locus & Primer sequence $\left(5^{\prime}->3^{\prime}\right)$ & PCR (bp) & Restriction enzyme & Reference \\
\hline PRL Exon 1 & $\begin{array}{l}\text { F: ATTATCTCTCTCATTTCCTTTCA } \\
\text { R: ACTCTGCTGTCACTGTCTGTATT }\end{array}$ & 857 & $\begin{array}{c}\text { RsaI } \\
\text { HaeIII }\end{array}$ & 25 \\
\hline PRL Exon 3 & $\begin{array}{l}\text { F: CGAGTCCTTATGAGCTTGATTCTT } \\
\text { R: GCCTTCCAGAAGTCGTTTGTTTTC }\end{array}$ & 156 & RsaI & 11 \\
\hline
\end{tabular}

PCR - polymerase chain reaction; PRL - prolactin; bp - base pair.

$\mathrm{F}$ - forward primer; $\mathrm{R}$ - reverse primer.

Table 2 - Obtained PRL genotypes

\begin{tabular}{lccccc}
\hline Gene & PCR $(\mathrm{bp})$ & Restriction enzyme & AA (bp) & AB (bp) & BB (bp) \\
\hline Exon 3 & 156 & RsaI & 156 & $156,82,74$ & 82,74 \\
\multirow{2}{*}{ Exon 1 } & \multirow{2}{*}{857} & RsaI & 857 & $857,323,243,125,89,77$ & $323,243,125,89,77$ \\
& & HaeIII & 857 & $857,663,194$ & 663,194 \\
\hline
\end{tabular}

PCR - polymerase chain reaction; PRL - prolactin; bp - base pair. 


\section{Results}

According to RE digestions of $\mathrm{PCR}$ products, amplifications from PRL exon 1 (Figure 1) and exon 3 (Figure 3) were observed. Polymorphisms of these exons were determined by RE digestion (Figures 2 and 4 ).

As seen from the PCR result of exon 1 (Figure 2), an additional band was located close to the expected fragment. The band mentioned above was observed as two bands in the same region when digested with HaeIII (Figure 2a). HaeIII digestion of the same exon resulted in a single allele (A) and a single genotype (AA) for all samples. Similarly, Rsal digestion of the same exon led to a single genotype (BB) and a single allele (B) for all samples (Figure 2b). RsaI digestion of PRL exon 3 was presented in a single

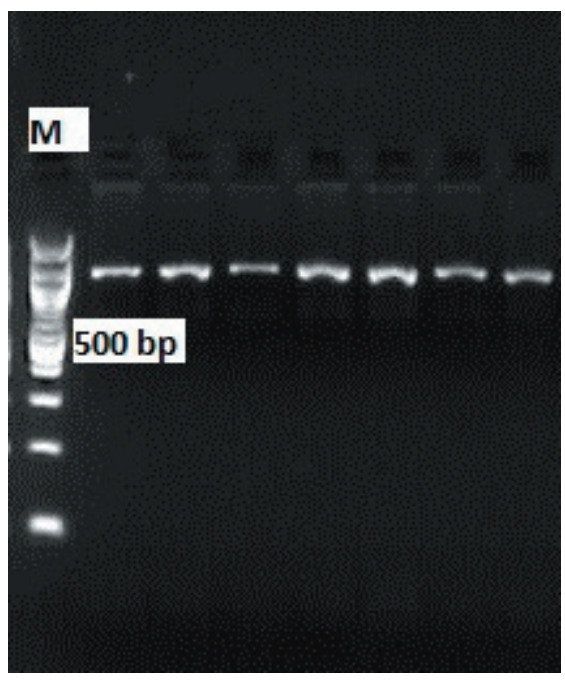

PCR - polymerase chain reaction; PRL - prolactin; bp - base pair. 857 bp band; $M$ for 100 bp Ladder.

Figure 1 - Results of PCR of exon 1 of PRL gene. genotype (AA) and a single allele (A) for all samples (Table 3). Hence, no PRL gene polymorphisms in Anatolian water buffalo breed were observed $(\mathrm{P}>0.05)$.

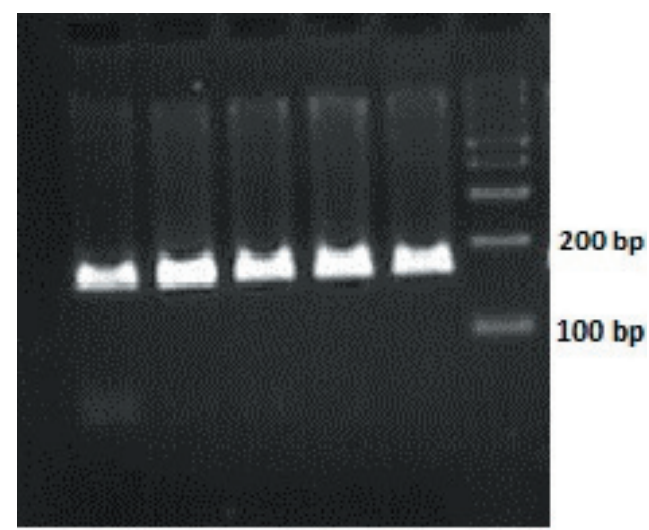

PCR - polymerase chain reaction; PRL - prolactin; bp - base pair. $156 \mathrm{bp}$ band; $\mathrm{M}$ for $100 \mathrm{bp}$ Ladder.

Figure 3 - Results of PCR of exon 3 of PRL gene.

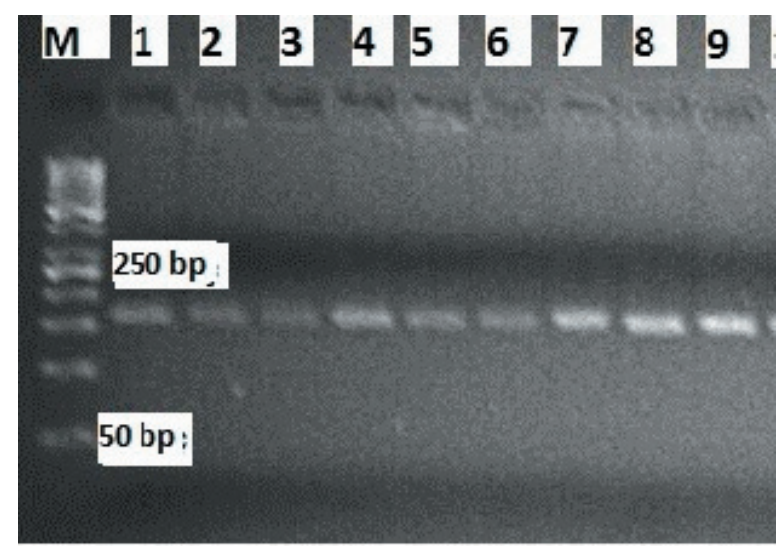

PRL - prolactin; bp - base pair.

1 to 16: samples with AA genotypes (156 bp); M for $100 \mathrm{bp}$ Ladder.

Figure 4 - Digestion results of exon 3 of PRL gene.
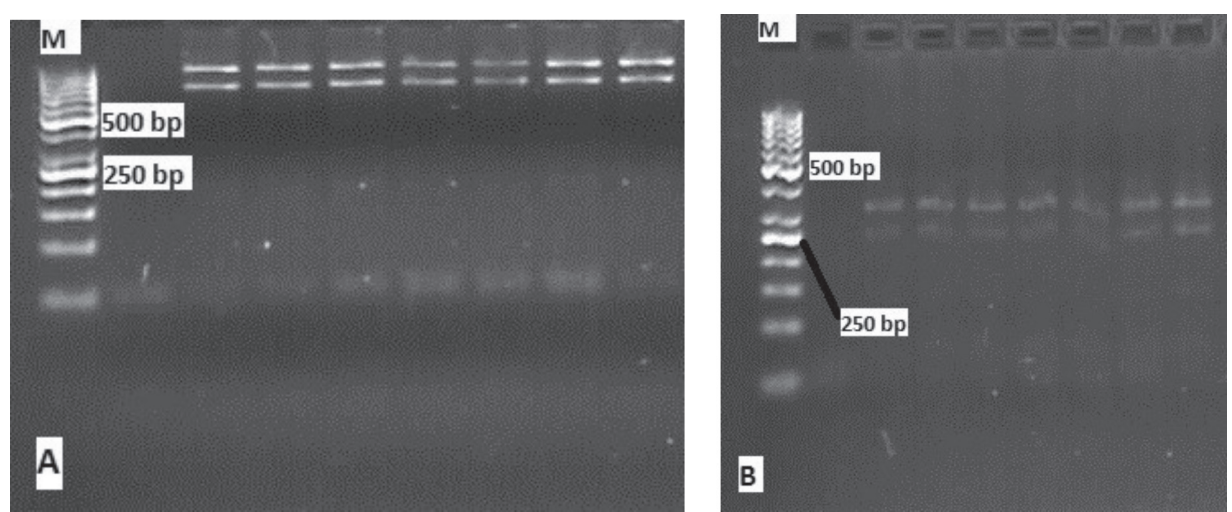

PRL - prolactin; bp - base pair.

A: HaeIII digestion; samples with AA genotype; $\mathrm{M}$ for $100 \mathrm{bp}$ Ladder

B: RsaI digestion; samples with BB genotype; $\mathrm{M}$ for 100 bp Ladder.

Figure 2 - Digestion results of exon 1 of PRL gene. 
Table 3 - Chi-square analyses, genotype and allelic frequencies, and significance of PRL genotypes

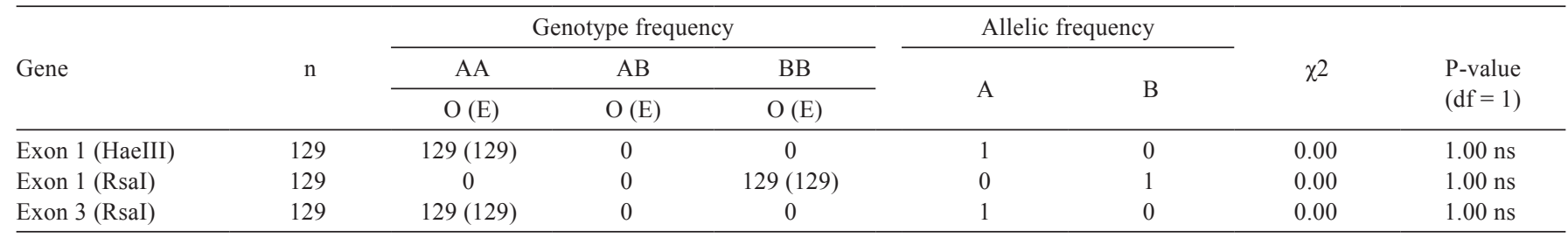

PRL - prolactin; O - observed; E - expected; $d f$ - degree of freedom; $\chi^{2}$ - Chi-square; ns - not significant at $P>0.05$.

\section{Discussion}

Polymorphism investigations in both cattle and water buffalo breeds were carried out for PRL exons. There are studies for exon 3 (Mitra et al., 1995; Kaplan and Boztepe, 2000; Alipanah et al., 2007; Kumari et al., 2008; Biradar et al., 2014; Konca and Akyüz, 2017) and for exon 1 (Ladani et al., 2003b; Madnalwar et al., 2010). However, PRL exon 3 has been the most extensively studied. Up to this point, only the HaeIII RE is used for digesting the PRL exon 1 . There are only two previous studies conducted with Anatolian water buffalo breed for PRL gene polymorphisms and only exon 3 was investigated (Kaplan and Boztepe, 2000; Konca and Akyüz, 2017).

In this present study, for the first time, both PRL exons 1 and 3 were examined at the same time in Anatolian water buffalo breed. Additionally, polymorphisms in PRL exon 1 was investigated for the first time by using both HaeIII and RsaI RE. Therefore, the present study is a novel addition to literature for Anatolian water buffalo breed and also for other studies conducted in different countries. Besides, the sample amount used for the present study is the highest for studies conducted in Anatolian water buffalo breed and is even higher than most studies conducted for different breeds.

HaeIII digestion of PRL exon 1 resulted in only AA genotype for Anatolian water buffalo breed. Similarly, only AA genotype was obtained from Pandharpuri water buffalo breed using the same RE (Madnalwar et al., 2010). In addition, PRL exon 1 was digested with RsaI RE in this study and resulted only BB genotype.

PRL exon 3 digestion with RsaI resulted only in AA genotype and only the A allele for Anatolian water buffalo breed. Similarly, only AA genotype was obtained from the Iranian (Tabar et al., 2010), the Murrah (Biradar et al., 2014), and the Anatolian (Kaplan and Boztepe, 2000) breeds. However, it has been reported that $\mathrm{AB}$ and $\mathrm{BB}$ genotypes, in addition to AA genotype, were found in Anatolian water buffalo breed (Konca and Akyüz, 2017). In previous studies, in which PRL exon 3 polymorphisms in Anatolian water buffalo breed were investigated, 45 animals were used by Kaplan and Boztepe (2000) and 126 animals were used by Konca and Akyüz (2017). Significantly more animals were used in the present study. Polymorphism studies carried out in other countries by using RsaI RE in both cattle and water buffalo breeds reported that the highest genotype received was AA, with a ratio of $55-93 \%$, and the highest allelic frequency was A with a ratio of 79-82\% (Mitra et al., 1995; Kaplan and Boztepe, 2000; Alipanah et al., 2007; Kumari et al., 2008). Nonetheless, there is another study in which AA genotype was not reported (Ladani et al., 2003a).

It has been reported that Anatolian water buffalo breed is similar in appearance to Mesopotamian breeds (FAO, 2005). Accordingly, it has been previously reported that monomorphic AA genotype was found as the breed characteristic for the Murrah water buffalo breed (Biradar et al., 2014). The AA genotype was mostly obtained from water buffalo breeds in Mesopotamia and in the present study, monomorphic AA genotype was obtained from Anatolian water buffalo breed.

\section{Conclusions}

Anatolian water buffalo breed has a dairy performance with high milk and milk fat yields since BB genotype was obtained in the present study.

\section{Acknowledgments}

This research was supported by the Scientific Research Project Fund of Cumhuriyet University under project number V-019. The study was presented as an oral presentation at The International Conference on Agriculture, Forest, Food Sciences and Technologies (ICAFOF 2017), 15-17 May 2017, Cappadocia, Turkey.

\section{References}

Alipanah, M.; Kalashnikova, L. and Rodionov, G. 2007. Association of prolactin gene variants with milk production traits in Russian Red Pied cattle. Iranian Journal of Biotechnology 5:158-161. 
Biradar, S. M.; Unaune, K. P.; Dodamani, S.; Mhatre, P. S.; Londhe, S. P.; Pawar, V. D.; Sawane, M. P. and Umrikar, U. D. 2014. Study of prolactin gene polymorphism in Murrah buffalo. Journal of Cell and Tissue Research 14:4065-4068.

Don, R. H.; Cox, P. T.; Wainwright, B. J.; Baker, K. and Mattick, J. S. 1991. 'Touchdown' PCR to circumvent spurious priming during gene amplification. Nucleic Acids Research 19:4008.

FAO - Food and Agriculture Organization of the United Nations. 2005. Buffalo production and research. Edited by Antonio Borghese. REU Technical Series 67. Available at: <ftp://ftp.fao.org/docrep/ fao/010/ah847e/ah847e.pdf > . Accessed on: Nov. 15, 2016.

Freeman, M. E.; Kanyicska, B.; Lerant, A. and Nagy, G. 2000. Prolactin: Structure, function, and regulation of secretion. Physiological Reviews 80:1523-1631.

Governmental Newspaper. 2004. 25668 say1l Yerli hayvan 1rk ve hatlarının tescili hakkında tebliğ. Tebliğ No: 2004/39, 12.12.2004

Governmental Newspaper. 2012. 28356 sayıl1 Hayvan genetik kaynakları yerinde koruma ve geliştirme desteklemeleri hakkında uygulama esasları tebliği. Tebliğ No: 2012/54, 17.07.2012.

Kaplan, S. and Boztepe, S. 2000. The determination of prolactin gene polymorphism using PCR-RFLP method within Indigenous Anatolian Water Buffalo and Brown Swiss. p.168-173. In: Proceedings of the 2nd International Symposium on Sustainable Development. Sarajevo, Bosnia \& Herzegovina.

Konca, M. A. and Akyüz, B. 2017. Investigation of growth hormone releasing hormone, growth hormone and prolactin hormone gene polymorphism in Anatolian water buffalo. Annals of Animal Science 17:1053-1062. doi: 10.1515/aoas-2016-0100.
Kumari, A. R.; Singh, K. M.; Soni, K. J.; Patel, R. K.; Chauhan, J. B. and Sambasiva Rao, K. R. S. 2008. Genotyping of the polymorphism within exon 3 of prolactin gene in various dairy breeds by PCRRFLP. Archiv Tierzucht Dummerstorf 51:298-299.

Ladani, D. D.; Pipalia, D. L.; Brahmkshtri, B. P.; Rank, D. N.; Joshi, C. G.; Vataliya, P. H. and Solanki, J. V. 2003a. Prolactin genotyping of Indian buffalo breeds using PCR-RFLP. Buffalo Journal 19:203-208.

Ladani, D. D.; Pipalia, D. L.; Brahmkshtri, B. P.; Rank, D. N.; Joshi, C. G.; Vataliya, P. H. and Solanki, J. V. 2003b. PCRRFLP polymorphism at prolactin locus in buffaloes. Buffalo Journal 19:237-242.

Madnalwar, V. S.; Sawane, M. P.; Pawar, V. D.; Patil, P. A.; Fernandis, A. P. and Bannalikar, A. S. 2010. Genotyping the prolactin gene in Pandharpuri buffaloes by PCR-RFLP. Buffalo Bulletin 29:88-91.

Michelizzi, V. N.; Dodson, M. V.; Pan, Z.; Amaral, M. E. J.; Michal, J. J.; McLean, D. J.; Womack, J. E. and Jiang, Z. 2010. Water buffalo genome science comes of age. International Journal of Biological Sciences 6:333-349.

Mitra, A.; Schlee, P.; Balakrishnan, R. and Pirchner, F. 1995. Polymorphisms at growth hormone and prolactin loci in Indian cattle and buffalo. Journal of Animal Breeding and Genetics 112:71-74.

Sambrook, J.; Fritsch, E. F. and Maniatis, T. 1989. Molecular cloning: A laboratory manual. p.9.16-9.19. 2nd ed. Cold Spring Harbor Laboratory Pres, Cold Spring Harbor.

Tabar, Y. S.; Fayazi, J.; Roshanfekr, H.; Mirzadeh, Kh. and Sadr, A. S. 2010. Investigation of prolactin polymorphism in buffalo population of Khuzestan-Iran by PCR-RFLP. Journal of Animal and Veterinary Advances 9:284-286. 